\title{
Factors Influencing Social Entrepreneurial Intention: A Case of a Private University in Bekasi
}

\author{
Anggraeni Permatasari \\ Faculty of Business, President University, Bekasi, Indonesia \\ anggraeni@ president.ac.id* \\ Garry Doohan \\ Faculty of Business, President University, Cikarang, Bekasi, Indonesia \\ gdoohan77@gmail.com \\ Muhammad Setiawan Kusmulyono \\ School of Business and Economics, Universitas Prasetiya Mulya \\ setiawan@pmbs.ac.id
}

\begin{abstract}
This study analyses the influence of emotional intelligence, self-efficacy, attitude, and subjective norms on university students' social entrepreneurial intention. Quantitative research was chosen in this study. Two hundred and five respondents participated in this study. Multiple Regression analysis was utilized as a statistical tool to test the hypothesis. This study found a significant influence between emotional intelligence, self-efficacy, attitude, and subjective norms toward social entrepreneurial intention (simultaneously). This study also defines which factors influence students to engage in social entrepreneurship projects in the private university context.
\end{abstract}

Keywords: Social Entrepreneurial Intention, Emotional Intelligence, Self-efficacy, Attitude toward Social Entrepreneur, Subjective Norms

\section{Introduction}

The concept of entrepreneurship is growing dynamically. Social entrepreneurship is an innovative and social activity that occurs within the nonprofit, business, or government sectors (Austin et al., 2006). The benefits of a social enterprise include creating job opportunities and promoting entrepreneurial skills to the community (Kusumasari, 2015). "Social entrepreneurship approach can be used to overcome social and environmental problems (Anggadwita et al., 2020)". By the time social value is given, social entrepreneurs are reviving economic value to secure their financial sustainability and life viability (Mair \& Marti, 2006). Ramadani et al. (2020) stated, "Public expectations continue to drive governments to develop new social innovations." Therefore, social entrepreneurship has become an increasingly important point for people's interest in recent years (Mair et al., 2006).

In 2018, the Ministry of Cooperatives and SMEs stated an increasing number of entrepreneurs from $1.6 \%$ to $3.1 \%$ of the population in Indonesia. With this excellent

*Corresponding Author 
number for its population of 250 million, Indonesia must have at least 5 million entrepreneurs (Kominfo, 2017). Global Entrepreneurship Monitor (GEM) annual report in 2015 shows Indonesia in the bottom position, far from the top 10 countries with the highest percentage of social entrepreneurs, and Indonesia is categorized as having a low level of growth for social entrepreneurs. According to UNESCAPBritish Council research, social enterprises could contribute $1.91 \%$ of Indonesia's GDP (19.4 Billion). However, Indonesia's growing number of social entrepreneurs is low, lower than other Southeast Asia Countries (Kominfo, 2017). Platform Usaha Sosial (PLUS) Researched stated there is 820 more start-up running social enterprises in Indonesia. Although the contribution is still low, it proves a strong relationship between social enterprise sustainability and economic growth (Kusumasari, 2015).

The GEM report shows that the Total Early Stage (TEA) rate of the adult population who have started a business is 18 - 64 years old. It raises an essential question for a university to adopt the social entrepreneurial curriculum toward social entrepreneurship since 18 years old is at the beginning of university. Therefore, the universities in Indonesia can develop their graduates to be young social entrepreneurs. "Social entrepreneurship can be nurtured through education by conducting social entrepreneurship courses in universities (Yudha \& Kusmulyono, 2018)". Universities can help the Government of Indonesia reduce social issues and positively impact community development, gender, local welfare advocacy, and disability (Tiwari et al., 2017). " Nation needs people's support to solve the problem" (Bikse et al., 2015). Following Anggadwita et al. (2020), sociopreneurs are people who can provide social impacts (outcomes) in increasing the economic capacity of the community and community empowerment. Therefore, this study utilizes an in-depth analysis and understanding of factors that influence social entrepreneurial intention.

This study aims to examine the influence of psychological factors on social entrepreneurial intentions among business higher education students. This paper selected the sample from a Private University located in Bekasi, West Java, Indonesia. The university was chosen because of its performance and commitment to applying an entrepreneurship curriculum through all faculties. The respondents were final year students from the faculty of business of the Private University who have experienced learning and implementing entrepreneurial subjects. This study will give contributions to future research in terms of academic purposes. The results can help develop strategies to maximize social entrepreneurs' potential in university by supporting a curriculum that constrains social learning process and innovation.

This paper is constructed with a research background to explain the urgency of this paper. In the next part, we describe the literature review, which constructs the conceptual framework. This study investigates four independent variables, such as emotional intelligence, self-efficacy, attitude, and subjective norms. The literature review explains the direct influence between those variables toward the social entrepreneurial intention. Then this paper explains in detail about research method. We choose the quantitative method using multiple regression analysis. Last, we 
explain the analysis of hypotheses testing and discuss the results to understand better which factors can influence students' social entrepreneurial intention.

\section{Literature Review}

\subsection{Emotional Intelligence}

Emotional intelligence (EI) is the ability to know and understand our own emotions, how we can manage ourselves, how to connect with others, and influence others' emotions (Goleman, 2011). Emotional intelligence is also meant to understand the capability to comprehend and manage a person to act prudentially in society. Emotional intelligence affects creativity, proactivity and plays an essential role in cultivating attitude toward innovation (Tsaousis \& Nikolau, 2005; Zampetakis et al.,2009). "Emotional intelligence involves the following elements: self-awareness, empathy, handling relationships, managing feelings, and motivation (Goleman, 2011)". From a business perspective, the role of emotions could affect the cause of success or failure in business (Shepherd, 2004; Humphrey, 2013). In the context of social entrepreneurship, a previous study by Tiwari et al. (2017) stated that emotional intelligence will always be used to predict social entrepreneurial intentions. Most of the social entrepreneurship research defines empathy as a critical element in developing social business. Emotional intelligence helps entrepreneurs gain empathy as part of social awareness (Humphrey, 2013; Tiwari et al., 2017). It concludes, to increase social entrepreneur intention, people also need to improve their emotional intelligence to supply more benefits/value. Therefore, we develop our first hypothesis as follows:

H1: Emotional Intelligence has a significant influence on social entrepreneurial intentions.

\subsection{Self-Efficacy}

Self-efficacy is a critical aspect of entrepreneurship. Self-efficacy (SE) leads to people's beliefs concerning their ability to implement control over their functioning level. This occasion affects their existence (Ajzen, 2002). Self-efficacy causes a differentiation between how people feel, think, and act. Feeling, depression, anxiety, and helplessness are associated with a low sense of self-efficacy (Schwarzer, 2014). In dynamic environments, self-efficacy reduces performance when combined with moderate optimism but impairs when combined with high optimism (Piperopoulus \& Dimov, 2014).

Moreover, in a dependable environment, the consequences of self-efficacy on performance is low. Self-efficacy drives a person to start a business and running through many obstacles and challenges (Cardon \& Kirk, 2013). Self-efficacy in social entrepreneurs is certainly very influential. Hockerts (2015) suggests that students' self-efficacy can be reared within social entrepreneurship education. Therefore, we developed the following hypothesis:

H2: Self-efficacy has a significant influence on social entrepreneurial intentions. 


\subsection{Attitude toward Social Entrepreneur}

An attitude tends to prevail toward or against something in the environment, thereby becoming positive or negative (Tiwari et al., 2017). Attitudes are decided by beliefs or faith that a specific behavior will guide a favorable outcome (Rauch \& Hulsink, 2015). Attitudes are based on individual thoughts and the process of evaluations associated with individual beliefs. In the entrepreneurial intention studies, attitude toward social entrepreneurs (ATSE) is guaranteed to be an essential factor that affects intention in a positive manner (Kocoglu \& Hassan, 2013). According to Ernst (2011), attitudes also have a powerful influence on entrepreneurial intentions. It's proved the effect of attitude toward becoming a social entrepreneur on Social Entrepreneurial Intentions (SEIs). There is a strong influence on people's attitudes toward social entrepreneurs. We also used ATSE to decide which students possess toward social entrepreneurs as a career option. Therefore, we propose the following hypothesis:

H3: Attitude toward social entrepreneurs has a significant influence on social entrepreneurial intentions.

\subsection{Subjective Norms}

Subjective norms $(\mathrm{SN})$ reveal "the personal beliefs relate to how they would be considered by society if they implement a specific behavior" (Al-Swidi et al., 2015). Subjective norms point out the social pressure experienced in deciding to do action and consider social pressure from the family, friends, and partners. Ajzen (1997) interpreted subjective norms as "the person's perception of social pressure" to perform the behavior under deliberation. The previous research concludes, there is a significant influence between subjective norms and social entrepreneurship intention from previous social entrepreneurship studies. Therefore, the developed hypothesis is as follow:

H4: Subjective norms have a significant influence on social entrepreneurial intentions.

\subsection{Social Entrepreneurial Intention (SEI)}

Behavior intention could be predicted and clarified by some personality's lifestyles and values (Chen \& Tung, 2014). Their study demonstrates that attitude, behavior, or intention must be at the same level of exclusivity. It cannot be expected that general attitudes will be strongly associated with individual behavior (Chen \& Tung, 2014). In the previous years, the concept of entrepreneurial intention and its predecessors have received increasing attention in entrepreneurship studies on predicting entrepreneurial behavior and understanding the interaction (Fayolle \& Gailly, 2015). The entrepreneurial intention is much needed toward the launch of the enterprise. The fact that social entrepreneurial intention (SEI) is challenging to develop, the role of environment and culture also influences entrepreneurial intention (Tiwari et al., 2017). In predicting entrepreneurial intention and behavior, it has to be recognized that the decision would be starting from the personality, 
personal values, attitudes, and perception which are not identical to the subject (Ernst, 2011). Motivations encourage people toward entrepreneurial intention and the perceived reward. The motivation for each person is probably different, depending on their values. Therefore, as suggested by Tiwari et al. (2017), the fifth hypothesis is as follows:

H5: Simultaneously, emotional intelligence, self-efficacy, attitude, subjective norms have significant influences on social entrepreneurial intentions.

From previous studies, we construct the conceptual model that consists of the following five hypotheses to test in this study:

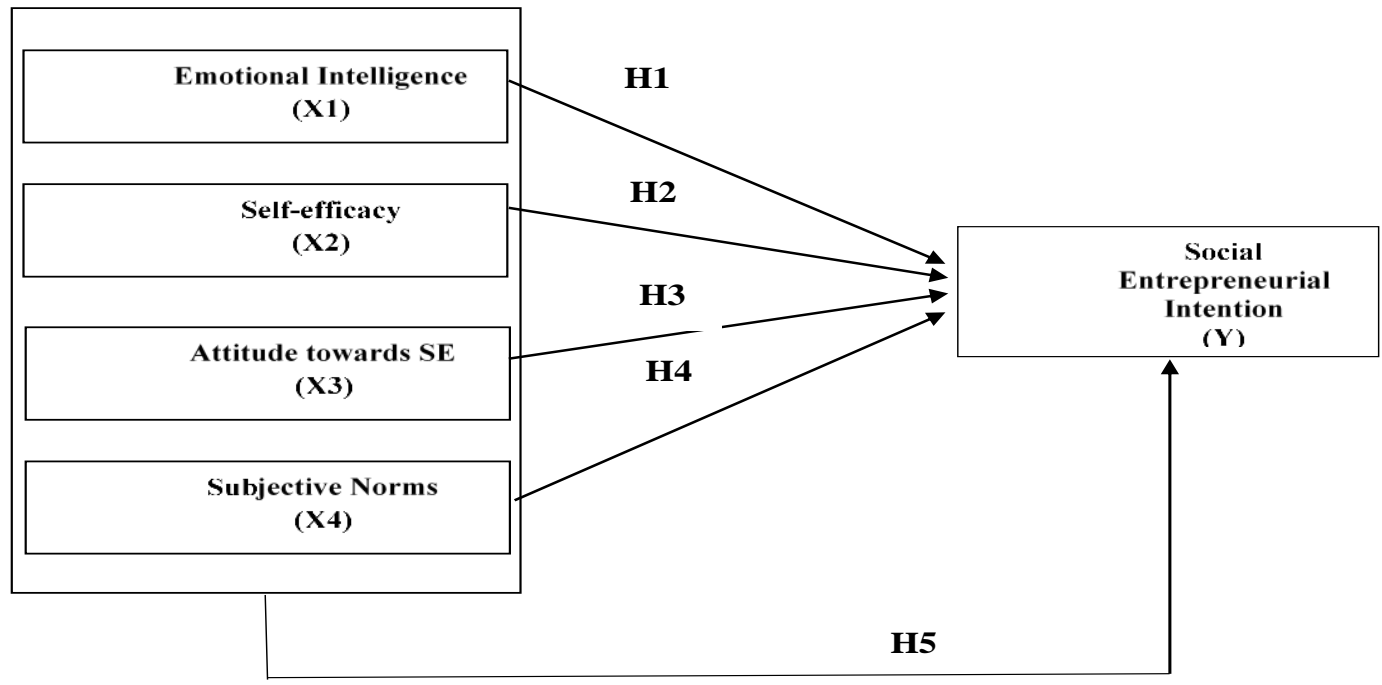

Figure 1. Conceptual Framework

\section{Research Methods}

The prominent nature of this study is a quantitative method with a survey approach. This study used the questionnaire to collect the primary data. For secondary data, the researcher used printed reports and news to describe the updated information about Indonesia's social entrepreneurship phenomena.

\subsection{Sample and Data Collection}

The population of this study is active students at a Private University in Bekasi. This study selected students in their final year in the Business Faculty as the best sample because they have experienced and implemented entrepreneurial courses. For data collection, we distributed an online questionnaire to the respondents. According to Sekaran \& Bougie (2016), A purposive sampling technique was used to define a suitable sample size; the sample should be above 30 respondents and less than 500 respondents. Three hundred questionnaires were distributed through 
Google form link and social media. Within 4-5 weeks, 268 data were collected, but only 205 valid data were collected. The screening result of 268 responses reveals that only 205 replies and 63 others stop screening questions. All data that meet requirements continue to the next step of data analysis.

\subsection{Research Instrument and Measurement}

The questionnaire is an instrument that provides a frame of questions distributed to the respondent. The questionnaire consists of three sections. The first section is screening questions to filter respondents, which asks whether the respondent has received any entrepreneur subject (lesson, training, workshop, etc.), understand about social entrepreneurship, and have an idea to start the social enterprise. The second section consists of demographic profiles such as gender, age, university, and faculty. The last is the variables section from the theoretical framework. This study used to construct measurement of 22 statements regarding variables of emotional intelligence (5 items), self-efficacy ( 4 items), attitude (4 items), subjective norms ( 3 items), and social entrepreneurial intention (6 items). The questionnaire is using a 6-point Likert scale, with a score of 1 for "strongly disagree," 2 for "disagree," 3 for "slightly disagree," 4 for "slightly agree," 5 for "agree," and 6 for "strongly agree."

\subsection{Data Analysis}

In the data analysis phase, we conduct the validity and reliability test, descriptive analysis, classical assumption test, multiple regression, and adjusted $\mathrm{R}$ square analysis. The validity test examines to answer theoretical questions about why the scale works and what deductions can be made regarding the underlying theory. According to Hair et al. (2011), the corrected Item-Total Correlation is used to test the validity of more than 0.3 . Meanwhile, the reliability test is assessed by determining the relationship between scores obtained from different scale administrations, with Cronbach's Alpha value of more or equal to 0.5, ideally 0.7 or higher. Descriptive statistics described what the data show. Meanwhile, the classical assumption test confirms that the data have passed some normality criteria, heteroscedasticity and multicollinearity.

Multiple regression analysis was used to test the hypothesis by using the T-test and F-test. Both tests is conducted to examine the effect of independent variables partially and simultaneously on the dependent variable. The T-test compares the differences between the two average values with the error standard of the difference in the two samples' average (Hair et al., 2011; Sekaran \& Bougie, 2016). Each hypothesis is tested with a real level of $\alpha=5 \%$. The last, the coefficient of determination, can be seen in the summary and written models. Simultaneously, the F-test is conducted to test whether the variables of emotional intelligence, selfefficacy, attitude toward social entrepreneur, and subjective norms with social entrepreneurial intention $(\mathrm{X} 1, \mathrm{X} 2, \mathrm{X} 3, \mathrm{X} 4)$ influence the variable of social entrepreneurial intention (Y). The F-test is done by comparing the level of significance set for the study with the probability value from research results. Adjusted R Square ranges from 0 to 1 . The adjusted $R^{2}$ is getting more valuable if 
significant-close to 1 , then it can be said that the influence of the free variable (X1, $\mathrm{X} 2, \mathrm{X} 3$, and $\mathrm{X} 4$ ) is considerable on the $\mathrm{Y}$ variable. It means that the model used is stronger to explain the influence of the independent variable studied on the dependent variable.

\section{Results and Discussion}

\subsection{Respondent's Profile}

This study analyzes respondents which most of them are active students from the faculty of business in one of the most prestigious private universities in Bekasi. The respondents' total number is 205 valid respondents, with 99 (48\%) female and 106 (52\%) male respondents. The percentage shows that male respondents are much higher than female respondents. The majority of the respondents are from the age group between $20-25$ years, with 116 respondents $(57 \%)$, followed by $15-20$ years old, with 87 respondents representing $42 \%$ of the research. The descriptive analysis helps measure extensive data in respondents who have experienced an entrepreneurial subject course during their study and know their social entrepreneurial intention.

Table 1. Respondents Profile

\begin{tabular}{llll}
\hline Variable & Category & Frequency, N & Percentage \\
\hline Gender & Female & 99 & $48 \%$ \\
& Male & 106 & $52 \%$ \\
Age & Total & 205 & $100 \%$ \\
\hline & $<15$ & 0 & $0 \%$ \\
& $15-20$ & 87 & $42 \%$ \\
& $20-25$ & 116 & $57 \%$ \\
& $26-30$ & 2 & $1 \%$ \\
& $>30$ & 0 & $0 \%$ \\
& Total & 205 & $100 \%$ \\
\hline
\end{tabular}

\subsection{Validity and Reliability Tests}

The pilot test uses the first 30 respondents to check the validity and reliability of the questionnaires. The results show that the Corrected item-total Correlation is more than r-table $=0,361$. The value of Cronbach's Alpha should be higher than 0.7. Therefore, from the results in Table 2 below, EI1 is not valid. Meanwhile, the other survey items are valid and reliable (acceptable). 
Table 2. The Corrected item-total Correlation

\begin{tabular}{|c|c|c|c|c|c|}
\hline & $\begin{array}{l}\text { Scale Mean if } \\
\text { Item Deleted }\end{array}$ & $\begin{array}{c}\text { Scale Variance } \\
\text { if Item } \\
\text { Deleted }\end{array}$ & $\begin{array}{l}\text { Corrected } \\
\text { Item-Total } \\
\text { Correlation }\end{array}$ & $\begin{array}{c}\text { Squared } \\
\text { Multiple } \\
\text { Correlation }\end{array}$ & $\begin{array}{c}\text { Cronbach's } \\
\text { Alpha if Item } \\
\text { Deleted }\end{array}$ \\
\hline$\overline{E I 1}$ & 102.13 & 149.821 & .294 & .319 & .908 \\
\hline EI2 & 102.27 & 146.540 & .363 & .327 & .907 \\
\hline EI3 & 101.82 & 148.492 & .399 & .358 & .906 \\
\hline EI4 & 102.06 & 144.854 & .503 & .426 & .904 \\
\hline EI5 & 101.73 & 149.168 & .436 & .327 & .905 \\
\hline SE1 & 102.08 & 147.004 & .427 & .337 & .905 \\
\hline SE2 & 102.37 & 145.027 & .406 & .355 & .906 \\
\hline SE3 & 102.28 & 144.302 & .447 & .348 & .905 \\
\hline SE4 & 102.74 & 144.614 & .362 & .412 & .908 \\
\hline ATSE1 & 101.85 & 142.939 & .672 & .592 & .900 \\
\hline ATSE2 & 102.01 & 144.304 & .578 & .496 & .902 \\
\hline ATSE3 & 101.96 & 144.876 & .592 & .540 & .902 \\
\hline ATSE4 & 102.36 & 139.712 & .673 & .595 & .900 \\
\hline SN1 & 101.89 & 143.688 & .493 & .505 & .904 \\
\hline SN2 & 101.87 & 146.252 & .513 & .506 & .904 \\
\hline SN3 & 101.92 & 146.004 & .481 & .490 & .904 \\
\hline SEI1 & 102.35 & 137.237 & .749 & .644 & .897 \\
\hline SEI2 & 102.55 & 138.622 & .636 & .580 & .900 \\
\hline SEI3 & 102.10 & 142.308 & .628 & .494 & .901 \\
\hline SEI4 & 102.17 & 139.972 & .689 & .627 & .899 \\
\hline SEI5 & 102.31 & 137.324 & .709 & .677 & .898 \\
\hline SEI6 & 102.19 & 140.367 & .663 & .648 & .900 \\
\hline
\end{tabular}

\subsection{Multiple Regression Analysis}

After the data meet the classical assumption test requirement, we continue to test five hypotheses constructed using multiple regression analysis. Hypothesis testing could be checked with the F-test and T-test. The F test's significance aims to determine whether all the independent variables (emotional intelligence, selfefficacy, attitude, and subjective norms) included in the model have a combined effect on the dependent variable (social entrepreneurial intention). The F-test can be seen from Table 3 column Sig with the condition that the result is smaller than 0.05 . The F-test result is $(\mathrm{f}=78.473 ; \mathrm{p}=0.0001)$, meaning that the independent variables significantly affect the dependent variable.

Table 3. F-test Results

\begin{tabular}{|c|c|c|c|c|c|c|}
\hline Model & & Sum of Squares & Df & Mean Square & $\mathrm{F}$ & Sig. \\
\hline 1 & $\begin{array}{l}\text { Regression } \\
\text { Residual } \\
\text { Total }\end{array}$ & $\begin{array}{l}3230.038 \\
2058.060 \\
5288.098\end{array}$ & $\begin{array}{l}4 \\
200 \\
204\end{array}$ & $\begin{array}{l}807.509 \\
10.290\end{array}$ & 78.473 & $.000^{\mathrm{b}}$ \\
\hline
\end{tabular}

a. Dependent Variable: SEI

b. Predictors: (Constant), SN, SE, EI, ATSE

Table 3 shows emotional intelligence, self-efficacy, attitude, subjective norms simultaneously influence social entrepreneurial intentions. The independent variables are interconnected and related to each other. However, emotional intelligence is a weak predictor of social entrepreneurial intention. This study supported Tiwari et al. (2017), who found an interconnected relationship between attitude and subjective norms with social entrepreneurial intention. 
The T-test results show positive and significant influences of self-efficacy, attitude, and subjective norms on the Private University students' social entrepreneurial intention. Based on the data analysis, four hypotheses have been tested partially. There are three hypotheses accepted and one hypothesis rejected. The accepted hypotheses are Self-efficacy on Social Entrepreneurial Intention $(t=4.795 ; \beta=0.430$; sig $\mathrm{P}=0.00)$, Attitude on Social Entrepreneurial Intention $(\mathrm{t}=9.932 ; \beta=1.025$; sig $\mathrm{P}=0.00)$, Subjective Norms on Social Entrepreneurial Intention $(\mathrm{t}=2.168 ; \beta=0.267$; sig $\mathrm{P}=0.31$ ). However, for Emotional Intelligence on Social Entrepreneurial Intention ( $\mathrm{t}=-0.134 ; \beta=-0.013$; sig $\mathrm{P}=0.894)$, emotional intelligence does not significantly influence the social entrepreneurial intention in the Private University as the t-test should be smaller than 0.05 . The researchers discuss this further in Table 4.

Table 4. T-test results



Emotional intelligence has no significant direct influence on social entrepreneurial intention. It proves the previous studies from Tiwari et al. (2017) and Zampetakis et al. (2009) that emotional intelligence should be mediated by attitude. The result indicated that emotional intelligence should be mediated by entrepreneurship attitude. Therefore, social entrepreneurial intention increases when students start their social enterprises.

Self-efficacy has a significant influence on students' social entrepreneurial intention (SEI). A previous study stated that students' self-efficacy had been found to relate to occupational interests selection in college (Boyd \& Vozikis, 1994). Hockerts (2015) also proved self- efficiency had demonstrated strong relationships with the SEI. ATSE has a significant influence on SEI. The result $\mathrm{H} 2$ supports Zampetakis et al. (2009). Tiwari (2017) and Permatasari (2018) confirmed social entrepreneurial intention appeared through attitude during entrepreneurial class and workshop.

Subjective norms have a significant influence on social entrepreneurial intention. The result contradicts the previous study of Ernst (2011) in which there is no direct relationship between SN and SEI. This study found SN has emerged as a strong factor that has shown an important positive relationship with SEI. Permatasari et al. (2018) also confirm that SN has a significant influence on SEI 


\subsection{Adjusted R Square}

Adjusted R Square aims to identify how much the independent variable's ability influences the dependent variable. Table 5 shows that the value of Adjusted $\mathrm{R}$ Square of 0.603 , which means $60.3 \%$ of the variation in social entrepreneurial intention, can be explained by its independent variables: emotional intelligence, self-efficacy, attitude, and subjective norms. In comparison, the remaining $39.7 \%$ can be explained by other variables not examined in this study.

Table 5. Adj. R Square Factor

\begin{tabular}{|c|c|c|c|c|c|}
\hline & & & & & \\
Model & $\mathrm{R}$ & R Square & $\begin{array}{c}\text { Adjusted R } \\
\text { Square }\end{array}$ & $\begin{array}{c}\text { Std. Error of the } \\
\text { Estimate }\end{array}$ & Durbin-Watson \\
\hline 1 & $.782^{\mathrm{a}}$ & .611 & .603 & 3.208 & 1.965 \\
\hline
\end{tabular}

a. Predictors: (Constant), SN, SE, EI, ATSE

b. Dependent Variable: SEI

\subsection{Discussion}

Based on the analysis, emotional intelligence has no direct influence on social entrepreneurial intention. This study supported the finding of previous studies. Emotional intelligence should be mediated with an attitude toward entrepreneurs (Zampetakis et al., 2009) and Perceived Desirability (Tiwari et al., 2017). This study measures emotional intelligence through self-awareness, handling relationships, managing feelings, empathy, and social motivation (Goleman, 2011). The results predict empathy (EI4) and social motivation (EI5) as the most valid and reliable indicators to measure emotional intelligence. These results are supported by Mair et al. (2006) and Yudho and Kusmulyono (2018), who identified empathy as the most critical element in forming social businesses. However, it is not the only factor. Humphrey (2013) also defines emotional intelligence as "an ability relates to job performance, leadership, physical and mental health. While empathy most related to leadership emergence". In the context of a university, we infer that a student's social entrepreneurial intention will increase if institutions were more concerned about developing empathy and social motivation in their curriculum (Yudha \& Kusmulyono, 2018). In psychology aspects, emotional intelligence serves as the strength to resolve abstract reasoning: to understand meanings, to comprehend the sameness and variance between two concepts, to compose potential generalizations, and to savvy when generalizations may not be suitable based on the context (Mayer et al., 2016). In addition, Emotional Intelligence in terms of social, health, education, and work outcomes of each individual has different consequences (Peña-Sarrionandia et al., 2015).

Other hypotheses (H2, H3, H4, H5) are supported. The second hypothesis, Selfefficacy, has a significant influence on students' SEI. This hypothesis confirmed that self-efficacy had been related to students' occupational interest selection in university (Boyd \& Vozikis, 1994; Permatasari et al., 2018). In comparison, 
Hockerts (2015) proved that self-efficiency had demonstrated strong relationships with the Social Entrepreneurship Intention. When entrepreneurs believe in their ability and mentality to perform the tasks and start the new venture, they are more likely to succeed (Cardon \& Kirk, 2013). Barnir et al. (2011) found a strong relationship between self-efficacy and social entrepreneurial intention. Defourny and Nyssens (2017, as cited in Pratono et al., 2020) stated, "The practices of social enterprises are related to the social initiative to address a social problem by adopting business approaches." Therefore, social entrepreneurship education encourages social entrepreneurial self-efficacy for students (Hockerts, 2015). The use of the vicarious learning model of the social entrepreneur should involve social persuasion and provide mastery experiences in the field.

The next hypothesis, attitudes toward social entrepreneurs have a significant influence on social entrepreneurial intention. A person who has a positive attitude toward starting their own business and appends it with their overall aim in life will form an entrepreneurial intention (Carsrud \& Brannback, 2011). The results confirm previous studies from Tiwari et al. (2017) and Permatasari et al. (2018), which stated social entrepreneurial intention would begin to appear through students' attitudes from entrepreneur class and workshop. Zampetakis et al. (2009) also proved a positive relationship between Attitude and Social Entrepreneurial Intention. This is supported by Anggadwita et al. (2020), who found that "when sociopreneurs running their businesses, they are inseparable from the social character possessed."

At the same time, subjective norms in this study have a significant influence on students' SEI (H4). Contrary to the previous study by Ernst (2011), the result stated there is no direct effect between subjective norms and social entrepreneurship intention (SEI). Subjective norms have appeared as a decisive factor that has shown a positive influence on SEI. Gelderen et al. (2008) also proved that there is a positive relation between Subjective Norms and Social Entrepreneurial Intention

The last hypothesis (H5), the effect of emotional intelligence, self-efficacy, attitude, and subjective norms toward social entrepreneurial intentions is supported. The independent variables are interconnected and related to each other. However, emotional intelligence is a modest predictor of a student's social entrepreneurial intention. Tiwari et al. (2017) also proved in their research that those independent variables are interconnected and related to attitude and subjective norms as the mediating variable.

\section{Conclusion}

The results conclude that four of five hypotheses are supported. The analysis showed that self-efficacy, attitude toward social entrepreneurs, and subjective norms significantly influence social entrepreneurial intention. In contrast, emotional intelligence partially has no significant influence on social entrepreneurial intention (SEI). On the other hand, emotional intelligence, selfefficacy, attitude, and subjective norms simultaneously have a significant influence on social entrepreneurial intentions (SEI). This concludes that the use of the 
vicarious learning model of social entrepreneurs should involve social persuasion. Therefore, to increase students' intention on social entrepreneurship, higher education institutions need to redesign the entrepreneurship curriculum to accommodate emotional intelligence in terms of empathy.

In theoretical contribution, this study provides a better understanding of emotional intelligence's role on social entrepreneurial intention. Meanwhile, for managerial implication, this study can be used to develop a strategic plan for the university to maximize the potential of students' social entrepreneurial intention through the learning process. For future research, this study suggests improving variable emotional intelligence by focusing on social awareness. This study also recommends expanding the sample analysis with different universities and conduct comparison research to get more in-depth data and reveal the influence of emotional intelligence toward social entrepreneurial intention in a different context.

\section{References}

Ajzen, I. (2002). Perceived behavioral control, self-efficacy, locus of control, and the theory of planned behavior 1. Journal of applied social psychology, 32(4), 665-683.

Ajzen, I., \& Fishbein, M. (1977). Attitude-Behavior Relations: A Theoretical Analysis and Review of Empirical Research. Psychological Bulletin, 8(5), 888-918.

Al-Swidi, A., Huque, S. M., Hafeez, M. H., \& Shariff, M. N. (2015). The role of subjective norms in theory of planned behavior in the context of organic food consumption. British Food Journal, 116(10), 1561-1580.

Anggadwita, G., Alamanda, D. T., Eshtrefi, L., Ramadani, V., \& Permatasari, A. (2020). Social characters as predictors of sociopreneurs' motivation. World Review of Entrepreneurship, Management and Sustainable Development, 16(4), 445-461

Austin, J., Stevenson, H., \& Wei-Skillern, J. (2006). Social and Commercial Entrepreneurship: Same, Different, or Both? Entrepreneuship Theory and Practice, 30(1), 1-22.

Barnir, A., Watson, W. E., \& Hutchins, H. M. (2011). Mediation and Moderated Mediation in the Relationship Among Role Models, Self-Efficacy, Entrepreneurial Career Intention, and Gender. Journal of Applied Social Psychology, 4(2), 270-297.

Bikse, V., Rivza, B., \& Riemere, I. (2015). The Social Entrepreneur as a Promoter of Social Advancement. Procedia-Social and Behavioral Sciences, 185, 469-478.

Boyd, N. G., \& Vozikis, G. S. (1994). "The Influence of Self-Efficacy on the Development of Entrepreneurial Intentions. Entrepreneurship Theory \& Practice, 18, 63-63.

Cardon, M. S., \& Kirk, C. P. (2015). Entrepreneurial passion as mediator of the self-efficacy to persistence relationship. Entrepreneurship theory and practice, 39(5), 1027-1050.

Carsrud, A., \& Brännback, M. (2011). Entrepreneurial motivations: what do we still need to know?. Journal of Small Business Management, 49(1), 9-26.

Chen, M.-F., \& Tung, P.-J. (2014). Developing an extended Theory of Planned Behavior model to predictconsumers' intention to visit green hotels. 
International Journal of Hospitality Management, 36, 221-230.

Defourny, J. \& Nyssens, M. (2017), "Mapping social enterprise models: some evidence from the ICSEM project", Social Enterprise Journal, 13(4), 318328.

Ernst, K. (2011). Heart over mind - An empirical analysis of social entrepreneurial intention formation on the basis of the theory of planned behaviour. unpublished dissertation University Wuppertal, Wuppertal, 6-307.

Fayolle, A., \& Gailly, B. (2015). The Impact of Entrepreneurship Education on Entrepreneurial Attitudes and Intention: Hysteresis and Persistence. Journal of Small Business Management, 53(1), 75-93.

Gelderen, M. v., Brand, M., Praag, M. v., Bodewes, W., Poutsma, E., \& Gils, A. v. (2008). Explaining entrepreneurial intentions by means of the theory of planned behaviour. Career Development International, 13(6), 538-559.

Global Entrepreneurship Monitor (2015). Global Report 2015/16. Global Report, 1-156. Available from https://www.gemconsortium.org/ [Accessed December 16, 2018]

Goleman, D. (2011). The brain and emotional intelligence: New insights. Regional Business, 94.

Hair Jr, J. F., Black, W. C., Babin, B. J., \& Anderson, R. E. (2011). Multivariate Data Analysis. New Jersey: Pearson International Edition.

Hockerts, K. (2015). The Social Entrepreneurial Antecedents Scale (SEAS): a validation study. Social Enterprise Journal, 11(3), 260-280.

Humphrey, R. H. (2013). The benefits of emotional intelligence and empathy to entrepreneurship. Entrepreneurship Research Journal, 3(3), 287-294.

Kocoglu, M., \& Hassan, M. U. (2013). Assessing Entrepreneurial Intentions of University Students: A Comparative Study of Two Different Cultures: Turkey and Pakistani. European Journal of Business and Management, 5(13), 243-252.

Kolvereid, L., \& Isaksen, E. (2006). New business start-up and subsequent entry into self-employment. Journal of business venturing, 21(6), 866-885.

Kominfo (2017). Great opportunity to become an entrepreneur in the digital age. Available from https://kominfo.go.id [Accessed September 17, 2018]

Krueger, N. (1993). The Impact of Prior Entrepreneurial Exposure on Perceptions of New Venture Feasibility and Desirability. Entrepreneurship Theory \& Practice, 18(1), 315-330.

Krueger Jr, N. F., \& Brazeal, D. V. (1994). Entrepreneurial potential and potential entrepreneurs. Entrepreneurship theory and practice, 18(3), 91-104.

Krueger, N. F., Reilly, M. D., \& Carsurd, A. L. (2002). Competing Model of Entrepreneurial Intentions. Journal of Business Venturing, 15(5), 411-432.

Kusumasari, B. (2015). The Business Model of Social Entrepreneurship in Indonesia. International Journal of Administrative Science and Organization, 22(3), 156-168.

Mair, J., \& Marti, I. (2006). Social Entrepreneurship Research: A Source of Explanation, Prediction, and Delight. Journal of World Business, 41(1), 3644.

Mair, J., Robinson, J., \& Hockerts, K. (2006). Social Entrepreneurship. New York: Palgrave Macmillan UK.

Mayer, J. D., Caruso, D. R., \& Salovey, P. (2016). The ability model of emotional intelligence: Principles and updates. Emotion review, 8(4), 290-300.

Permatasari, A., Nugraha, R., \& Hadiansah, I. (2018). Analisis Relevansi 
Pendidikan Kewirausahaan dan Lingkungan Kampus Terhadap Minat Berwirausaha Mahasiswa Perguruan Tinggi di Jawa Barat, Indonesia. Jurnal Ilmu Sosial Politik Dan Humaniora, 1(2), 1-9.

Piperopoulos, P., \& Dimov, D. (2015). Burst bubbles or build steam? Entrepreneurship education, entrepreneurial self-efficacy, and entrepreneurial intentions. Journal of Small Business Management, 53(4), 970-985.

Pratono, A. H., Prima, D. A., Sinaga, N. F. N. T., Permatasari, A., Ariani, M., \& Han, L. (2020). Crowdfunding in digital humanities: some evidence from Indonesian social enterprises. Aslib Journal of Information Management, 72(2), 287-303.

Ramadani, V., Anggadwita, G., Welsh, D. H., \& Permatasari, A. (2020). Social innovation in public sector services. International Journal of Public Sector Performance Management, 6(3), 416-433.

Rauch, A., \& Hulsink, W. (2015). Putting entrepreneurship education where the intention to act lies: An investigation into the impact of entrepreneurship education on entrepreneurial behavior. Academy of management learning \& education, 14(2), 187-204.

Peña-Sarrionandia, A., Mikolajczak, M., \& Gross, J. J. (2015). Integrating emotion regulation and emotional intelligence traditions: a meta-analysis. Frontiers in psychology, 6, 160.

Schwarzer, R. (Ed.). (2014). Self-efficacy: Thought control of action. Taylor \& Francis.

Sekaran, U., \& Bougie, R. (2016). Research methods for business: A skill building approach. John Wiley \& Sons.

Shepherd, D. A. (2004). Educating Entrepreneurship Students About Emotion and Learning From Failure. Academy of Management Learning and Education,. 3(3), 274-287.

Tiwari, P., Bhat, A. K., \& Tikoria, J. (2017). The role of emotional intelligence and self-efficacy on social entrepreneurial attitudes and social entrepreneurial intentions. Journal of Social Entrepreneurship, 8(2), 165-185.

Tsaousis, I., \& Nikolau, I. (2005). Exploring the Relationship of Emotional Intelligence with Physical and Psychological Health Functioning. Stress and Health, 21(2), 77-86.

UNESCAP-British Council. (2018) Developing an Inclusive and Creative Economy: The State of Social Enterprise in Indonesia. Available from https://www.unescap.org/sites/default/files/the_state_of_social_enterprise _in_indoensia_british_council_web_final.pdf/ [Accessed December 16, 2018]

Yudha, D., \& Kusmulyono, M. (2018). The Effect of Social Entrepreneurship Education on Students Ability to Social Business Opportunity Identification and Social Presence. Asian Journal of Entrepreneurship and Family Business, 2(2), 123-129.

Zampetakis, L. A., Kafetsios, K., Bouranta, N., Dewett, T., \& Moustakis, V. S. (2009). On the relationship between emotional intelligence and entrepreneurial attitudes and intentions. Entrepreneurial Behaviour \& Research, 15(6), 595-618. 